\title{
Variables Affecting Economic Development of Wind Energy
}

Conference Paper NREL/CP-500-43506 July 2008

E. Lantz and S. Tegen National Renewable Energy Laboratory

Presented at WINDPOWER 2008 Houston, Texas June 1-4, 2008 


\section{NOTICE}

The submitted manuscript has been offered by an employee of the Midwest Research Institute (MRI), a contractor of the US Government under Contract No. DE-AC36-99G010337. Accordingly, the US Government and MRI retain a nonexclusive royalty-free license to publish or reproduce the published form of this contribution, or allow others to do so, for US Government purposes.

This report was prepared as an account of work sponsored by an agency of the United States government. Neither the United States government nor any agency thereof, nor any of their employees, makes any warranty, express or implied, or assumes any legal liability or responsibility for the accuracy, completeness, or usefulness of any information, apparatus, product, or process disclosed, or represents that its use would not infringe privately owned rights. Reference herein to any specific commercial product, process, or service by trade name, trademark, manufacturer, or otherwise does not necessarily constitute or imply its endorsement, recommendation, or favoring by the United States government or any agency thereof. The views and opinions of authors expressed herein do not necessarily state or reflect those of the United States government or any agency thereof.

Available electronically at http://www.osti.gov/bridge

Available for a processing fee to U.S. Department of Energy and its contractors, in paper, from:

U.S. Department of Energy

Office of Scientific and Technical Information

P.O. Box 62

Oak Ridge, TN 37831-0062

phone: 865.576 .8401

fax: 865.576 .5728

email: mailto:reports@adonis.osti.gov

Available for sale to the public, in paper, from:

U.S. Department of Commerce

National Technical Information Service

5285 Port Royal Road

Springfield, VA 22161

phone: 800.553 .6847

fax: 703.605.6900

email: orders@ntis.fedworld.gov

online ordering: http://www.ntis.gov/ordering.htm 


\section{Contents}

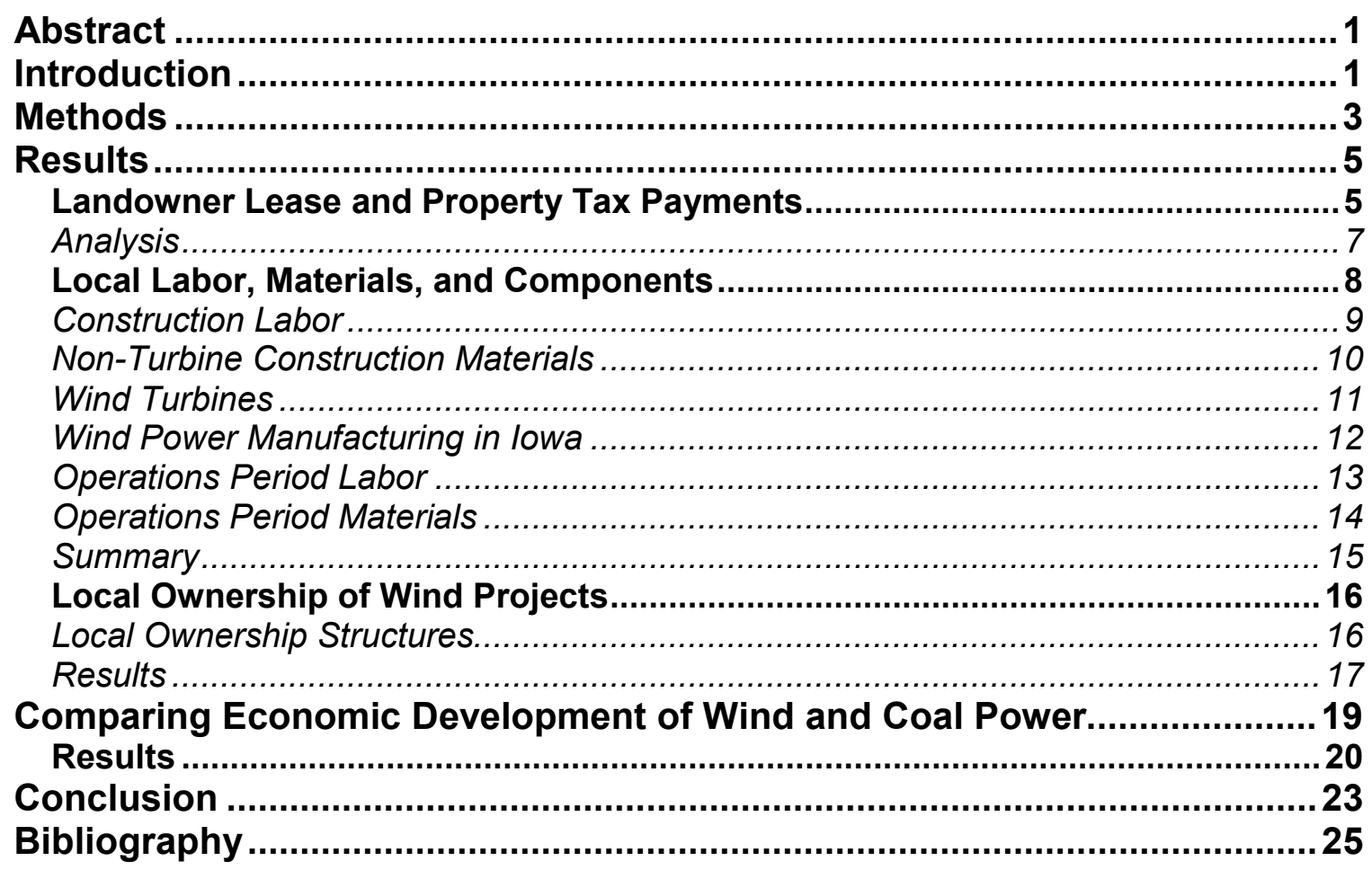




\section{Abstract}

As electricity demand increases, policymakers must make decisions about which energy resources will meet future demands. Much of the recent literature has focused on the contribution of new coal power plants to carbon emissions (Milford et al., 2005; Milford et al., 2007; MIT 2007). However, policymakers and industry are increasingly interested in job creation and economic development analyses to understand the full impacts of new electricity generation projects. ${ }^{1}$ Additionally, economic development impacts are often a critical piece in building public support for wind power projects.

The purpose of this research is to look at the specific factors that drive wind-powerrelated economic development and to better understand the impact of specific economic development variables on new wind project economic benefits. We also compare economic development impacts of wind and coal power.

We used the National Renewable Energy Laboratory's (NREL's) latest Jobs and Economic Development Impacts Wind (JEDI Wind) model to perform a sensitivity analysis of wind-power-related economic development drivers, and economic development benefits for wind and coal were estimated using NREL's JEDI Wind and JEDI Coal models.

Our research shows that economic development impacts can be dramatically enhanced through the development of local wind power manufacturing industries. We determined that if $10 \%$ of the wind turbine supply, for 1000 megawatts (MW) of development, is manufactured in-state, then construction-period economic development benefits are $68 \%$ greater than if all wind turbines are imported from out of state. On a secondary level, benefits are enhanced by developing and maintaining a skilled operations and maintenance labor force. Preliminary work shows that ownership structures that rely on local equity are likely to enhance in-state economic benefits, but our research suggests the majority of this benefit will accrue from the return on equity associated with a profitable wind project. Finally, we find that the economic development impacts of wind are generally forecast to exceed those of coal (except in some cases when coal consumed in new coal power plants is supplied by an in-state mining industry).

\section{Introduction}

The United States (U.S.) Energy Information Administration's (EIA's) Annual Energy Outlook 2008 forecasts total electricity use to grow at an average annual rate of $1.1 \%$ over the time period 2006-2030. Such growth is expected to bring an increase in electricity consumption of 30\% over 2006 levels and will require more than 120 gigawatts $(\mathrm{GW})$ of new generating capacity to be brought on line between 2006 and 2030 .

\footnotetext{
${ }^{1}$ This statement is based on the authors' experience providing state outreach in NREL's Wind Powering America Program. Economic development impacts are frequently and increasingly requested by high-level policymakers, including state energy offices, state Governor's offices, and occasionally Public Utilities Commissions.
} 
The EIA projects that the bulk of this new electricity demand will be met by new coalfired power plants. However, as the number of proposed coal plants has increased, the environmental community has become increasingly critical of new coal power generation. ${ }^{2}$ Furthermore, as public concern regarding carbon emissions has increased ${ }^{3}$ and the cost of clean energy alternatives, such as wind, has declined in recent decades (Wiser and Bolinger 2008), policymakers have begun to include the concepts of energy independence, price stability, and economic development in their thinking about new energy investments.

New energy generation constitutes a major investment, often on the order of hundreds of millions or potentially billions of dollars (O'Connell and Pletka 2007). Such spending results in widespread economic development, often in the form of increased work opportunities, higher salaries, and new customers for local business (Tegen 2006). Estimating the local or in-state economic development impacts allows decision-makers to incorporate economic development in their decision-making. Given an economic development impacts analysis, decision-makers are able to assess impacts based not only on the cost of energy but also on a project's ability to provide jobs and economic growth within a given constituency. Furthermore, understanding the drivers of economic development as it relates to new energy projects can allow policymakers to tailor local policy so that their economic development benefits are enhanced.

The purpose of this paper is to consider the various drivers of local economic development impacts from wind power and to ascertain the sensitivity of local economic development benefits to specific parameters. This is performed to highlight specific areas in which policy action would most efficiently increase economic development benefits and to direct the research of other analysts to the most critical parameters in wind power economic development research. In addition, we compare the local economic development impacts of new wind projects with those of new coal projects.

Our research suggests that land lease payments and property taxes are often critical in securing local landowner and public support for a given project. Although our sensitivity analysis shows that they only represent a portion of the total economic benefits, they should not be overlooked when considering wind projects or policies that are designed to increase the economic benefits of new wind projects. In addition, policies that increase the local manufacturing of wind turbines and components for in-state use by as little as $10 \%$ can increase statewide economic benefits during construction by $68 \%$. Policies that

\footnotetext{
${ }^{2}$ Such concern is evidenced by increasing public opposition to proposed new coal power plants. Institutions including the Sierra Club (http://www.sierraclub.org/environmentallaw/coal/) and Western Resource Advocates (a Boulder, Colorado-based environmental law and policy group, (http://www.westernresourceadvocates.org/energy/coal/index.php) have mounted widespread campaigns against new coal-fired power plants.

${ }^{3}$ Public concern has reached the point at which it is influencing public policy. One example is in the state of Kansas, where Governor Kathleen Sebelius upheld the State Department of Environment and Health's refusal to permit construction of proposed new coal-fired power plants on the basis of carbon dioxide emissions. In addition, Governor Sebelius has vetoed multiple state bills that would require construction on the plants to move forward. For more information see Sebelius prevents and reduces pollutants with veto, executive order. Office of the Governor of Kansas. Nicole Corcoran Press Secretary. March 21, 2008. http://www.governor.ks.gov/news/NewsRelease/2008/nr-08-0321a.htm
} 
ensure local labor is well trained and available for operations and maintenance work will keep economic benefits local over the life of the project by reducing monetary leakage to other states and regions. Preliminary research suggests that local project ownership may result in benefit increases on the order of $79 \%$ to $164 \%$ depending on the ownership structure and the rate of return on investment. Finally, with current levels of locally sourced labor, materials, and fuel, the economic development benefits of wind power frequently outweigh those of coal, except when a coal-fired power plant is able to acquire a large portion of its fuel from in-state coal resources.

\section{Methods}

To analyze the economic development benefits of wind power, we conducted research and interviews to obtain data for modeling inputs. Applicable information was acquired from state-specific electric industry contacts, local tax officials, wind power project developers, federal energy databases, press releases of proposed new wind and coal facilities, and state mining associations. ${ }^{4}$

We used NREL's latest JEDI ${ }^{5}$ models to estimate economic development benefits of wind and coal. We used the JEDI Wind model to assess sensitivity of wind power economic development parameters. Economic development benefits were calculated at the state level. For our sensitivity study, analyses were run for $1000 \mathrm{MW}$ of wind power. To compare wind and coal economic development benefits, we considered a 500-MW coal power plant and an equivalent-energy-producing wind power facility. ${ }^{6}$ Standard JEDI model inputs for this research are summarized below (Tables 1 and 2).

Table 1. Summary of Standard Default Inputs

\begin{tabular}{ccc} 
& Wind Power & Coal Power \\
\hline Capacity Factor & $33 \%-44 \%$ & $85 \%$ \\
\hline Construction Cost & $\$ 1,800 / \mathrm{kW}$ & $\$ 1,830 / \mathrm{kW}$ \\
\hline $\begin{array}{c}\text { Operations and } \\
\text { Maintenance }\end{array}$ & $\$ 24.70 / \mathrm{kW} / \mathrm{yr}$ & $\$ 48.00 / \mathrm{kW} / \mathrm{yr}$ \\
\hline Property Tax & $\$ 2,900-\$ 21,400 / \mathrm{MW} / \mathrm{yr}$ & $\$ 7,100-\$ 20,600 / \mathrm{MW} / \mathrm{yr}$ \\
\hline Fuel Cost & $\mathrm{n} / \mathrm{a}$ & $\$ 1.10-\$ 1.43 / \mathrm{mmbtu}$ \\
\hline Landowner Royalty & $\$ 2,667 / \mathrm{MW} / \mathrm{yr}$ & $\mathrm{n} / \mathrm{a}$ \\
\hline
\end{tabular}

\footnotetext{
${ }^{4}$ This data is cited as NREL Economic Development Database in the rest of this report.

${ }^{5}$ The JEDI Wind Model was developed by Marshall Goldberg of MRG \& Associates. It can be downloaded from NREL at http://www.nrel.gov/analysis/jedi/.

${ }^{6} \mathrm{New}$ coal power plants typically operate with a higher capacity factor than wind power plants. As a result, a larger nameplate capacity (MW) in wind power is required to produce the same amount of energy (megawatt-hours) as a 500-MW coal power plant. In this case, we used state-specific wind capacity factors to determine the number of MW of wind power required to produce the same amount of energy as a 500MW coal power plant. Our wind and coal comparisons are based on facilities that are estimated to produce approximately 3,723,000 MWh annually.
} 
Table 2. Default Scenario Local Supply Percentages

\begin{tabular}{ccc}
\hline & Wind Power & Coal Power \\
\hline $\begin{array}{c}\text { Basic Construction } \\
\text { Materials and General } \\
\text { Facility Equipment }\end{array}$ & $78 \%$ & $15 \%$ \\
\hline Construction Labor & $70 \%$ & $19 \%$ \\
\hline Turbine Equipment & $0 \%$ & $\mathrm{n} / \mathrm{a}$ \\
\hline $\begin{array}{c}\text { Miscellaneous } \\
\text { Construction Costs }\end{array}$ & $77 \%$ & $4 \%$ \\
\hline O\&M Labor (wind) & $100 \%$ & $\mathrm{n} / \mathrm{a}$ \\
\hline O\&M Materials (wind) & $63 \%$ & $\mathrm{n} / \mathrm{a}$ \\
\hline Fixed Costs (coal) & $\mathrm{n} / \mathrm{a}$ & $61 \%$ \\
\hline Variable Costs (coal) & $\mathrm{n} / \mathrm{a}$ & $62 \%$ \\
\hline
\end{tabular}

Economic development impacts analyses were performed for Colorado, Michigan, and Kansas. Each state represents a unique set of wind and coal resources, a different energy policy environment, and a distinctive work force. In some cases, interstate variability is minimal, and data are only presented for an individual state.

Sensitivity analyses were performed for property tax payments, land lease payments, local coal supply, wind turbine manufacturing, local labor, local non-turbine materials, and local wind plant ownership. Sensitivity scenarios were limited to manipulation of the local supply value for the parameters noted above and were based on adjustments of default JEDI inputs and state-specific landowner lease and property tax payments.

Results are presented as constant (2008) dollars and full-time equivalent (FTE) jobs. Construction period impacts represent the total construction period impacts regardless of the length of the construction process. ${ }^{7}$ Annual impacts represent the expected annual impacts for each year of operations. Cumulative, or total impacts, are based on the construction period plus 20 years of operations.

Our results represent the total impacts resulting from wind or coal project development. They are not intended to represent the $n e t^{8}$ benefit experienced from a given investment in new energy generation. Our comparison of wind and coal economic development uses estimates of wind power total economic development benefits and compares this value with an estimate of the total economic development from coal power.

\footnotetext{
${ }^{7}$ If the construction period lasts more than 1 year, annual construction period impacts may be determined by dividing construction period impacts by the number of years required for construction.

${ }^{8}$ The net benefit is defined as the specific benefit above and beyond a given alternative or set of alternatives.
} 
Finally, our results represent the expected impacts based on the current status of the wind industry and the current distribution of benefits. In time, such factors may change as a result of economic structure changes in the states that are analyzed, increased efficiencies in the industry, changes in state or federal policy, or a change in labor, turbines, and/or raw material supply relationships.

\section{Results}

We focused our analysis on four elements of economic development impacts. First, we assessed the role of landowner lease payments and local property taxes. We considered the magnitude of these payments, implications of variability in these parameters, and their proportion of the total, cumulative, economic development impacts. Second, we examined variability in local labor use and in purchasing of local goods and services that are utilized in wind projects. This allowed us to assess which aspects of project construction and operations will have the largest impact on state-level economic development. As a part of this analysis, we analyzed the role of local manufacturing in economic development analysis and considered the potential impacts of increased reliance on local manufacturing. We also display the projected changes in total economic benefits that may accrue in Iowa as a result of the emerging wind manufacturing industry there. In addition, we considered the role of local ownership structures in shaping economic development impacts. Finally, we compared the economic development benefits of wind and coal and considered the role of a local coal industry in the economic development benefits of coal power.

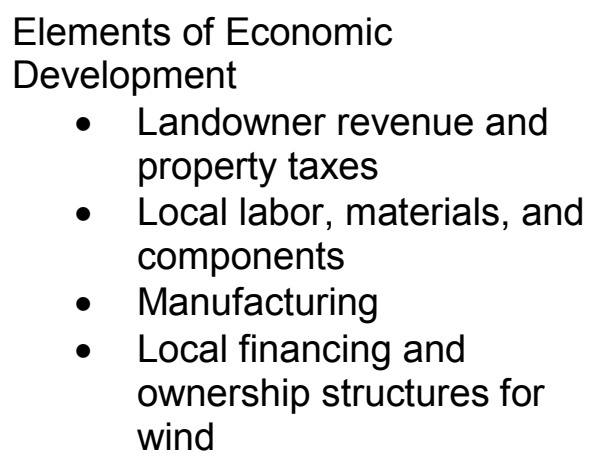

- Landowner revenue and property taxes

- Local labor, materials, and components

- Manufacturing

- Local financing and ownership structures for wind

\section{Landowner Lease and Property Tax Payments}

Landowner lease payments represent a sizable direct economic impact. Frequently on the order of $\$ 2,700-\$ 2,900 / \mathrm{MW},{ }^{9}$ these payments constitute millions for wind projects on the order of $375 \mathrm{MW}$ and greater. In addition, they constitute a direct payment to rural landowners that on a per-acre basis is much greater than the gross revenue from common agricultural crops including corn, wheat, and soybeans. ${ }^{10}$ Likewise property tax payments are a large benefit to local communities; averaging $\$ 8,000-\$ 9,000 / \mathrm{MW},{ }^{11}$ these payments

\footnotetext{
${ }^{9}$ NREL economic development database

${ }^{10}$ Assuming approximately 1 acre/MW and based on the average yield per acre for irrigated corn, wheat, and soybeans using 2002 USDA Ag. Census data available at (http://www.agcensus.usda.gov/Publications/2002/Volume 1, Chapter 1 US/index.asp) and July 2008 prices listed on the Chicago Board of Trade (http://www.cbot.com/) on May 20, 2008, farms can expect gross profits of \$945/acre, \$571/acre, and \$574/acre respectively. Furthermore, wind turbines on leased land require no farmer inputs except the additional resources required to navigate around the obstructions created by the turbines.

${ }^{11}$ NREL economic development database
} 
can increase the local tax base allowing for budget increases or a lowering of the taxing district's general tax rate. ${ }^{12}$

Our research revealed that land lease payments vary across the country. Figure 1 shows the direct, indirect, and induced impacts in Kansas from variable land lease payments. The high and low scenarios shown (Figure 1) are representative of the range of payments made to landowners across the Great Plains and provide a sense of how variability in land lease payments impacts economic development. This range results in economic impacts that are roughly $\$ 2.0$ to $\$ 8.0$ million from $1000 \mathrm{MW}$ of development. When considered as a part of the total economic impact, landowner lease payments typically make up less than $10 \%$ of the total economic impact over the life of the project.

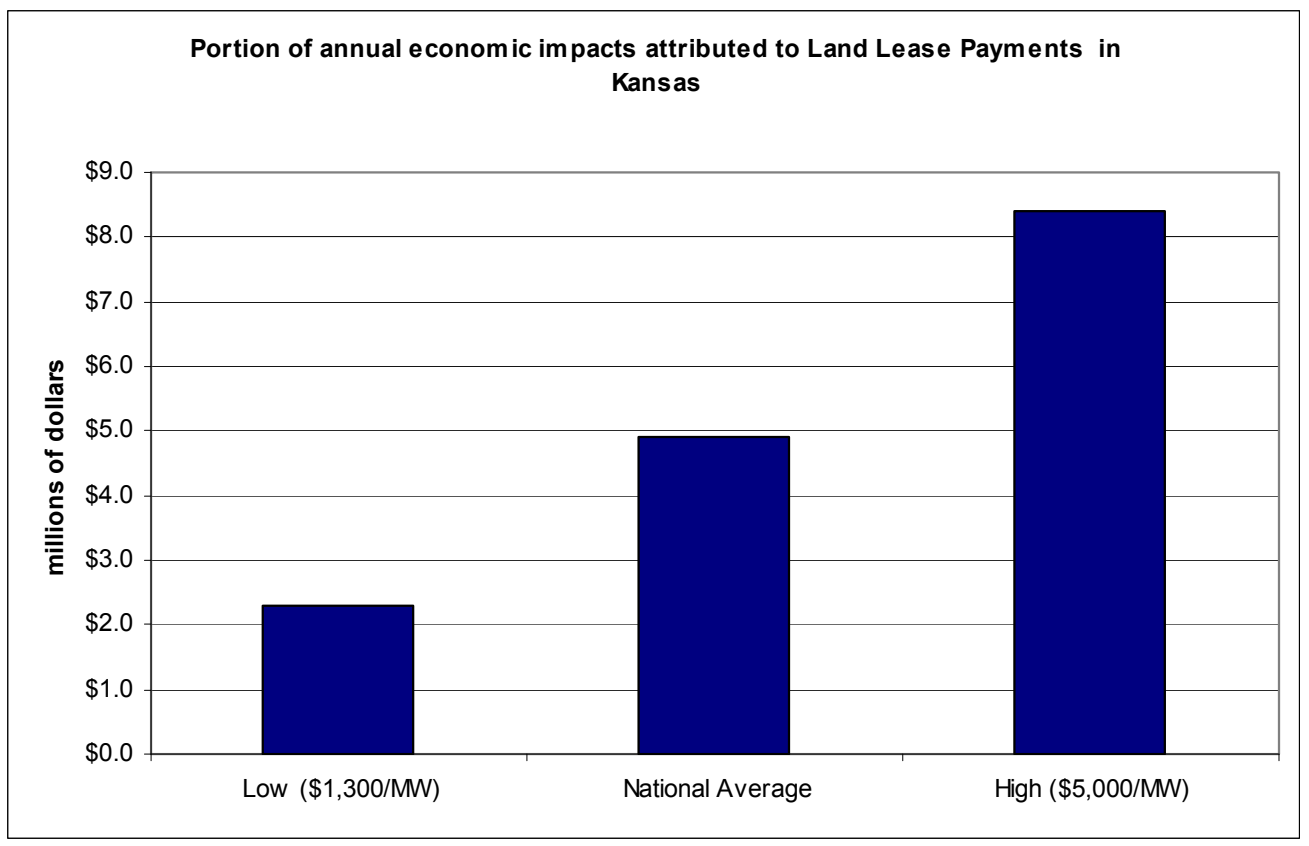

Figure 1. Variable land lease payment implications on economic development from 1000 MW of wind power ${ }^{13}$

Similarly property tax payments are often of significant interest, and wind power projects are widely recognized for their contributions to local taxing districts. ${ }^{14}$ However, our research indicates that property tax payments have a wide range from $3 \%$ to $22 \%$ of the

\footnotetext{
${ }^{12}$ The Lamar Wind Farm in southeastern Colorado (162 MW) is estimated to currently contribute more than $\$ 1.2$ million per year to the local taxing district (Prowers County Treasurer's Office 2008). Though this contribution declines as assets depreciate, such payments are typical of wind farms, and this demonstrates the dramatic impact these investments can have on the rural tax base.

${ }^{13}$ Reported values represent portion of total (direct, indirect, and induced) economic output that is attributed to land lease payments. Because a portion of these payments are reinvested and spent locally, this value is larger than the total direct payment. This condition is also true in respect to property taxes (Figure 2).

${ }^{14}$ A specific case is highlighted by the Prowers County, CO Chamber of Commerce http://www.lamarchamber.com/new\%20website/windfarm.html. In addition, popular press coverage frequently cites property tax payments from these developments in the form of contributions to local school districts or other public works.
} 
total project lifetime economic impacts. Variability occurs at the interstate level as well as between taxing districts within a given state. ${ }^{15}$ Figure 2 shows the impacts of property tax variability on annual economic development impacts. Estimated tax is based on the average state tax rate while the alternative scenarios represent moderate deviations from the estimated state average.

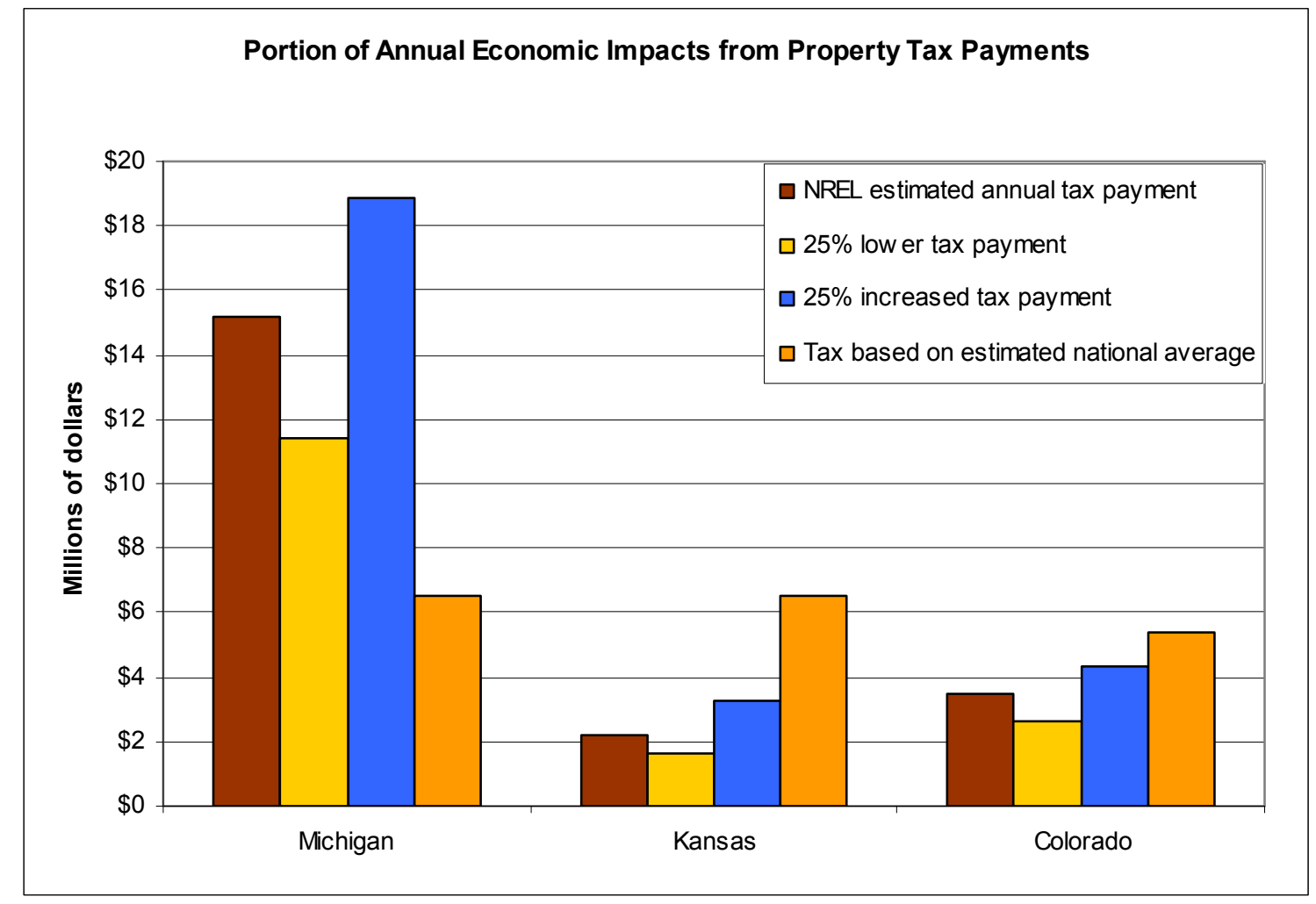

Figure 2. Economic development implications from variable property tax payments on $1000 \mathrm{MW}$ of wind power

In Figure 2, it is important to note that the bars represent the direct, indirect, and induced spending due to the amount of money the county or state retained for the property tax payment. The fourth orange bar is based on the national average payment of $\$ 8,700 / \mathrm{MW}$ in each state, but because Michigan and Kansas have higher economic multipliers in the wind industry, the same payment will provide a larger benefit to their in-state residents.

\section{Analysis}

While landowner lease payments and property tax payments generally constitute a moderate portion of economic development impacts, the high-profile, direct nature of these payments suggests that state and local communities are likely to pay increased attention to these parameters if they are thinking about policy to promote wind development.

\footnotetext{
${ }^{15}$ NREL economic development database
} 
Policymakers may have little direct influence over land lease payments. These arrangements are typically priced by the market and may depend on the local wind resource, local property values, access to transmission, and developer or corporate practice. However, policymakers may be able to enhance the value of land lease payments secondarily by establishing education and outreach programs for landowners with high-quality wind sites, or by facilitating transmission infrastructure development to wind resource areas. Such efforts may serve to increase landowner knowledge regarding the value of their property ${ }^{16}$ and ensure that viable resource sites are accessible to developers.

As noted in Figure 2, the magnitude of property tax benefits varies widely. Kansas and Michigan represent two opposite extremes in this regard. With this in mind, property tax policy may present a conundrum for state and local governments. Some states have chosen to provide property tax abatements with the hope that the reduction in property taxes will provide incentives for wind power development. On the other hand, a property tax abatement coupled with relatively low payments in lieu of tax, as is observed in Kansas, ${ }^{17}$ means foregoing millions of dollars in economic development benefits.

Since a typical property tax contribution to economic development is about $10 \%$ of lifetime development impacts, policymakers may feel that it is reasonable to reduce property tax rates to promote wind power development. If policymakers do reduce the property tax burden to the developer to account for the lost tax benefit, a policymaker may seek to promote wind power manufacturing investment and wind power training of the states' labor force. However, such a policy may result in a transfer of development benefits from rural taxing districts to the urban manufacturing and commercial construction sectors. In addition, it may reduce public support for wind power in rural communities where wind resources are abundant. To that end, in some cases, reducing property taxes or providing property tax abatements for wind power may not be the preferred incentive for wind development.

\section{Local Labor, Materials, and Components}

For the purpose of this analysis, local labor, materials, and components are defined as instate labor, materials, and components. These economic development factors are also referred to as local supply parameters. To analyze the impacts of local supply parameters, we divided a wind project investment into five categories:

- Construction labor

- Non-turbine-related construction materials

\footnotetext{
${ }^{16}$ The implication here is that increased landowner knowledge may increase land lease payments by increasing the awareness and therefore power of the landowner who is negotiating land access. However, full awareness of property and resource value may or may not result in increased landowner lease payments.

${ }^{17}$ Kansas exempts wind power plants from property taxes. In place of property taxes, wind power producers make payments in lieu of tax (PILOT). While these payments vary, the early precedent established these payments to be in the $\$ 2,900 / \mathrm{MW}$ range (Personal Communication, Kansas State Energy Office). Our modeling of Kansas property tax impacts relies on this value.
} 
- Wind turbines ${ }^{18}$

- Operations period (O\&M) labor

- Operations period (O\&M) materials.

In each category, we developed a high, low, and most likely (or default) scenario to assess the extent of change that results from varying the percentage of local labor and components that are derived from in-state suppliers. Default scenarios represent current JEDI assumptions based on national averages that were developed primarily through interviews with the wind industry. High and low scenarios are based on the variability we observe in existing projects and the potential implications of trends that have been observed anecdotally in interviews with project developers and industry experts.

\section{Construction Labor}

Economic development considerations typically focus a great deal of attention on local jobs. In addition, because of the relatively high capital costs associated with wind power projects, construction period jobs are an important piece of economic development impacts. In the past, JEDI research has determined that local labor supplies approximately $70 \%$ of the construction period jobs. However, more recent anecdotal observations suggest that this category may experience a high level of variability among projects and among developers. This is especially true in rural regions where construction labor is not familiar with wind projects or may not be readily available. However, our analyses demonstrate that from an economic development perspective, trends toward decreased local construction labor may not be a great concern. ${ }^{19}$

Construction labor represents large benefits in a brief time period. However, adjusting instate labor supply from $70 \%$ to $40 \%$ in Colorado only reduces the total construction period economic development benefits by $4 \%$. Furthermore, increasing the local construction labor supply from $70 \%$ to $90 \%$ brings an increase in construction period economic development benefits of only $3 \%$ (Figure 3 ).

\footnotetext{
${ }^{18}$ Including towers, blades, gearboxes, and rotors

${ }^{19}$ The underlying driver for this phenomenon is that construction labor costs represent a relatively small proportion of construction costs. To the extent the construction labor provides local jobs, it may be important. However, the inherently brief nature of wind project construction jobs diminishes their value for economic development purposes.
} 


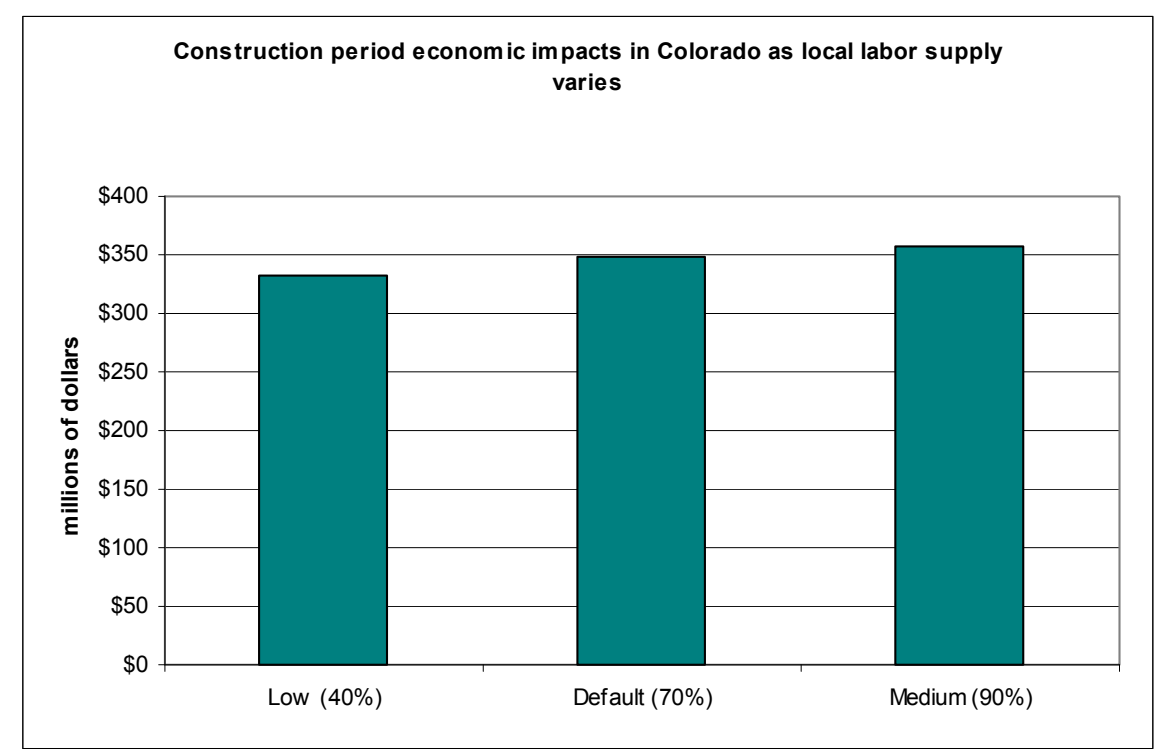

Figure 3. Construction period economic development variability associated with local labor supply variability (1000 MW of wind power)

\section{Non-Turbine Construction Materials}

Many wind farms rely heavily on non-turbine construction materials like sand, gravel, asphalt, and concrete for construction of roads and foundations. In addition, wind projects require general electrical construction materials. Due to their prevalence in conventional construction industries, most regions are capable of supplying a high level of the former category of materials to wind projects.

In this analysis, we considered three alternative scenarios from our standard assumption that $78 \%$ of local materials come from in-state suppliers. Reducing local materials supplies in Colorado from $78 \%$ to $50 \%$ results in a decline of $38 \%$ in construction-period impacts. Increasing local material supplies from $78 \%$ to $90 \%$ results in an increase of $9 \%$ in construction period impacts (Figure 4). 


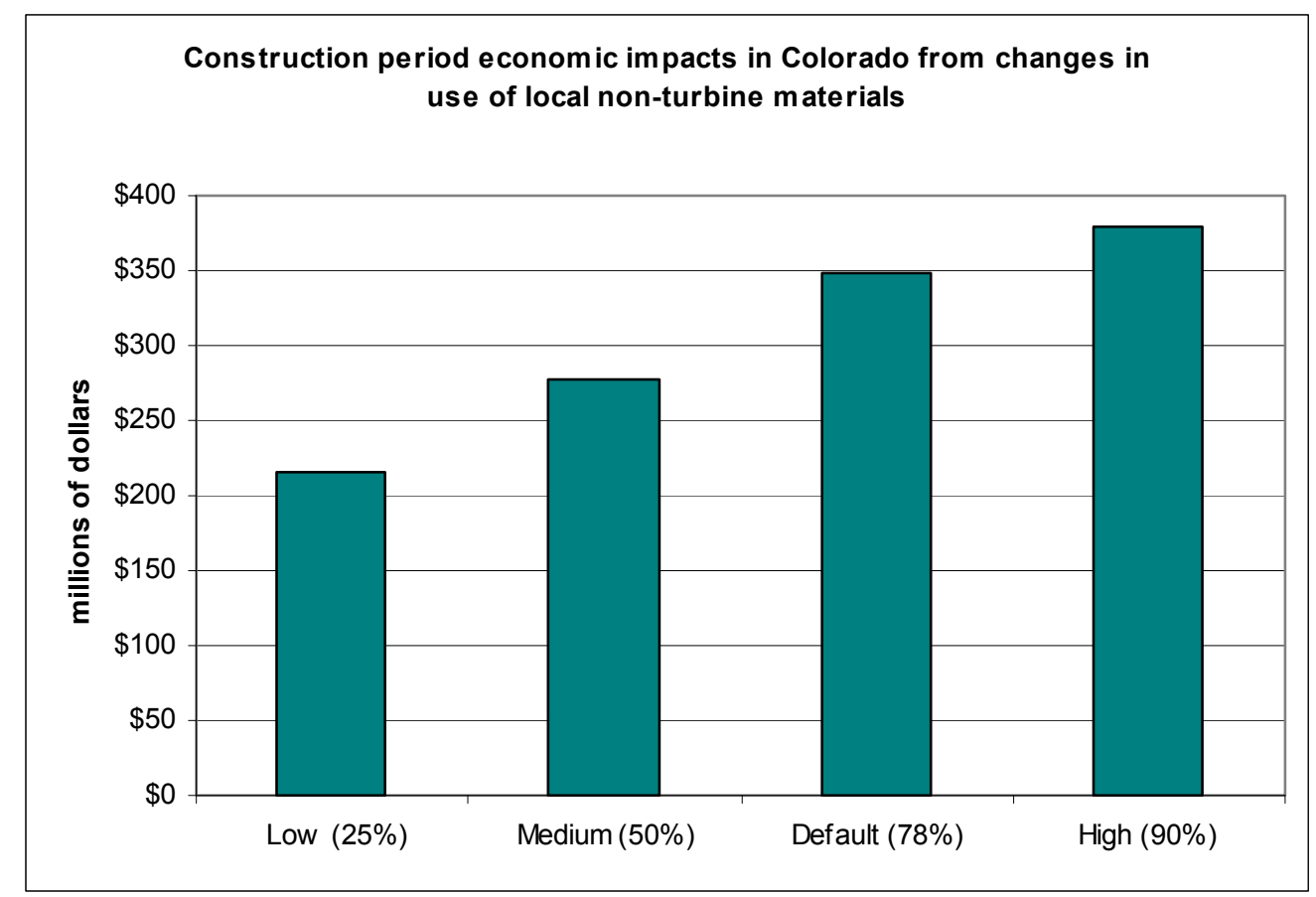

Figure 4. Construction period economic development variability associated with local non-turbine material supply variability (1000 MW of wind power).

As a part of the total cumulative economic benefits, reducing utilization of local materials to levels of $50 \%$ and below begins to have a dramatic impact on local economic development. However, due to the relatively commonplace nature of traditional materials like sand, concrete, and gravel and our experience in interviewing wind project developers, it is our perspective that we are unlikely to see local materials supply change significantly from the standard, default JEDI value. ${ }^{20}$

\section{Wind Turbines}

Our research suggests that the single greatest local supply parameter affecting economic development benefits is the supply of wind turbines and their components. Wind turbines frequently constitute $65 \%$ to $85 \%$ of the total construction cost for a new wind farm. ${ }^{21}$ As a result, increasing the in-state supply of wind turbines from 0 to $10 \%$ provides a $68 \%$ increase in construction-period economic development impacts. Moving from 0 to $50 \%$ in-state manufacturing generates a $341 \%$ increase in construction-period impacts.

As such, the single largest potential driver of economic development benefits is local manufacturing. Policymakers seeking to maximize economic development benefits from wind power are likely to gain the greatest increased benefit by attracting new wind power

\footnotetext{
${ }^{20}$ Based on our surveys, it is very common for developers to obtain local gravel, sand, and concrete in high levels ( $90 \%$ and more). Local supply of electrical materials has a higher degree of variability. However, our research suggests that basic materials like gravel, concrete, and sand comprise the largest proportion of non-turbine-related construction materials. As a result, we feel it is unlikely that usage of local material supplies will change dramatically in the near future. Furthermore, it is unlikely that policy measures will have a significant impact on use of local non-turbine construction materials; generally project developers utilize local construction materials if they are available.

${ }^{21}$ NREL economic development database
} 
manufacturing to their state. Figure 5 illustrates the potential change in jobs created for Michigan given $1000 \mathrm{MW}$ of wind development under local manufacturing scenarios from 0 to $50 \%$.

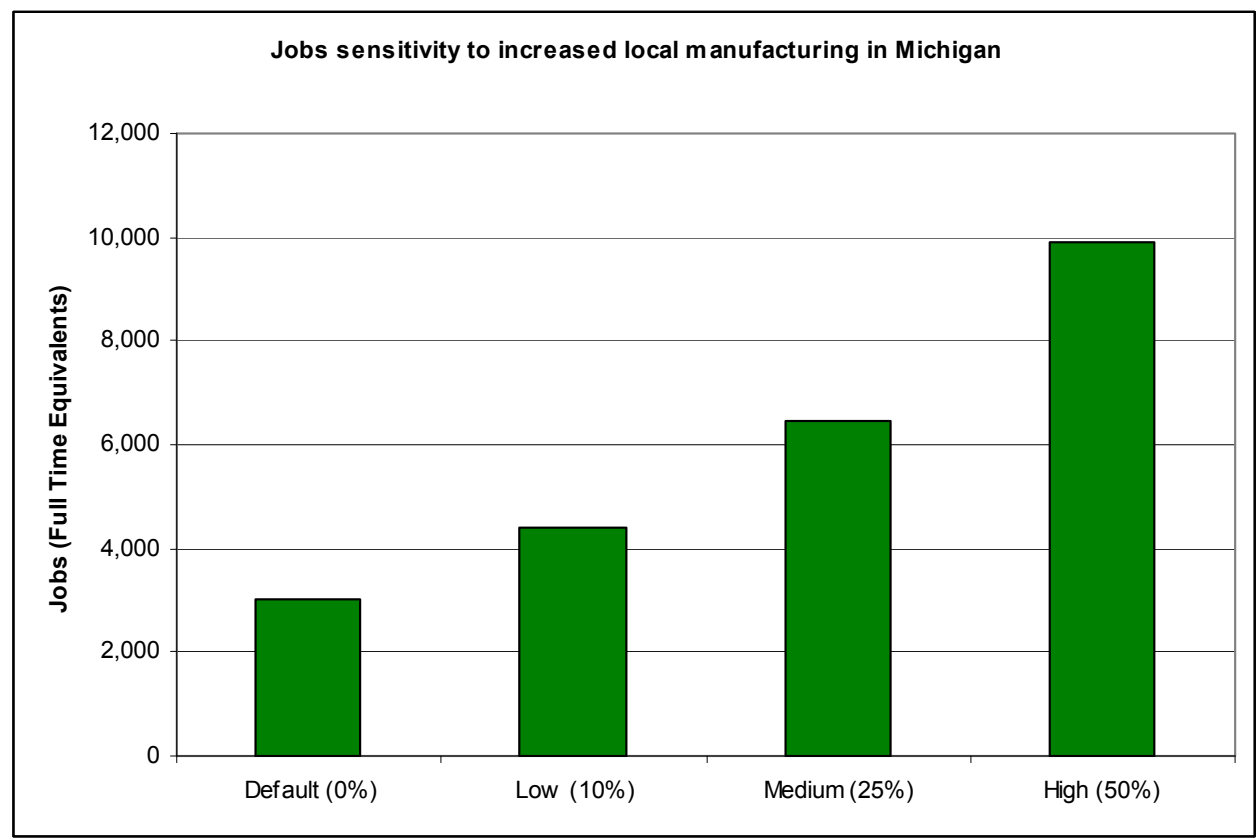

Figure 5. Construction Period Jobs Impacts in Michigan from increased reliance on local manufacturing (1000 MW of wind power)

\section{Wind Power Manufacturing in lowa}

Iowa is one of the leading states in terms of installed wind power capacity. In addition, it is the leading state for large-scale wind power manufacturing. Presently, there are six major existing or planned manufacturing facilities in Iowa which, when completed, will have the capacity to supply more than 1,000 MW of turbine blades and turbine generator components. ${ }^{22}$ In addition, it is estimated that $13 \%$ of current proposed projects in Iowa have selected turbines that could be manufactured by facilities in the state. ${ }^{23}$ Based on this information, we developed three scenarios for Iowa that demonstrate the potential economic development impacts that in-state manufacturing can provide from Iowa's next $2,400 \mathrm{MW}$ of wind power. ${ }^{24}$ Figure 6 highlights the results of this analysis.

\footnotetext{
${ }^{22}$ Two tower manufacturers have announced plans to build production facilities in Iowa; however, recent developments suggest that one of these proposed facilities may fall through. It is possible that these facilities will also produce at least $1000 \mathrm{MW}$ of turbine towers annually. However, potential production numbers from these facilities are not yet known.

${ }^{23}$ Data provided by personal communication with a major wind power developer in Iowa and a database of proposed projects maintained by Global Energy Concepts http://www.globalenergyconcepts.com/.

${ }^{24}$ The first scenario is the projected total economic impact in the absence of Iowa-based manufacturing. The second scenario is based on proposed projects in the state and relies on projects that have identified a specific turbine manufacturer. It assumes that turbine suppliers will use their Iowa-based facilities to supply Iowa projects that use their turbines. This number may ultimately vary if output from local facilities is committed to supplying wind projects outside of the state or if additional proposed projects ultimately select turbines that are being manufactured in the state. Our third scenario is based on a case in which $35 \%$ of the turbines, towers, and blades installed in Iowa are manufactured there. We believe this to be a
} 


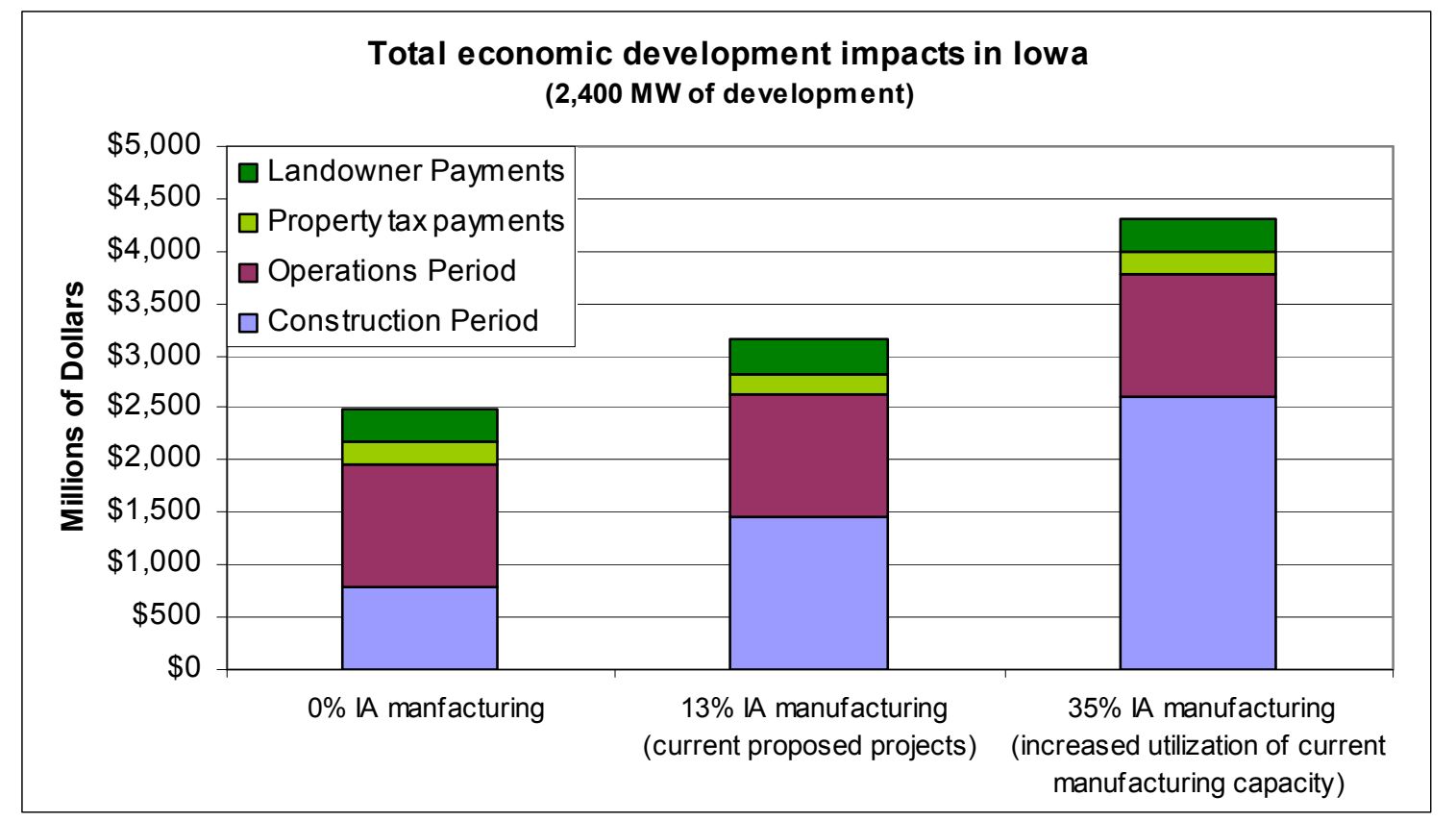

Figure 6. Economic development benefits for lowa with different levels of local manufacturing

In this analysis, the moderate scenario, based on proposed projects, demonstrates a $24 \%$ increase in total lifetime economic development benefits while the $35 \%$ local manufacturing case increases the total lifetime economic benefits by $70 \%$. This analysis demonstrates that large economic development benefits are likely to result from attracting local manufacturing to a given state. However, attracting wind power manufacturing may require intentional efforts and local policy support. Much of Iowa's success at attracting manufacturing facilities has resulted from provision of local incentives for new manufacturing projects as well as the states broader recognition of the value of wind power and its benefits for the state (Levesque 2008, AWEA press release 2008, and NREL Economic Development Database).

\section{Operations Period Labor}

In addition to wind turbine supply changes, local supply of materials and labor during the operations period of a wind power plant's life can have a notable impact on annual economic impacts. Such changes in operations period impacts are critical because of their implications for the total economic impact incurred over the life of the project. Default JEDI assumptions assume that O\&M labor is fully derived from within the state where development has occurred and that $63 \%$ of the materials utilized for wind turbine maintenance and repair are derived from in-state suppliers. In the past, O\&M labor has been provided extensively by in-state labor, and this is likely to continue for daily site operations. However, recent evidence suggests that wind farm maintenance may be

reasonable, incremental increase in manufacturing based on the diversity of manufactures present in the state, the large number of proposed projects that have not yet identified a turbine supplier, the lower transport costs associated with Iowa-based development, and the high level of manufacturing capacity that is expected from these facilities. 
evolving toward a contractor industry. ${ }^{25}$ If routine maintenance is performed by crews that travel from one wind farm to the next performing regular and major maintenance, states may see a drop in local labor utilized during the operations.

Based on this evidence and our default scenario that assumes 100\% local labor, we analyzed the impacts scenario for O\&M labor with medium and low local labor supplies of $25 \%$ and $50 \%$ respectively. The observed declines in annual economic impacts associated with these lower scenarios were on the order of $15 \%$ and $23 \%$ for the medium and low scenarios respectively in Kansas (Figure 7). Over a 20-year operations period, this change can represent as much as a $\$ 117$ million loss in economic development benefits if O\&M labor supply drops from $100 \%$ to $50 \%$ in-state and a $\$ 176$ million loss if the in-state labor supply drops from $100 \%$ to $25 \%$ in-state. In order to minimize lost economic development benefits, policymakers seeking to increase economic development benefits may benefit from increased workforce training programs to ensure that local labor is capable and competitive.

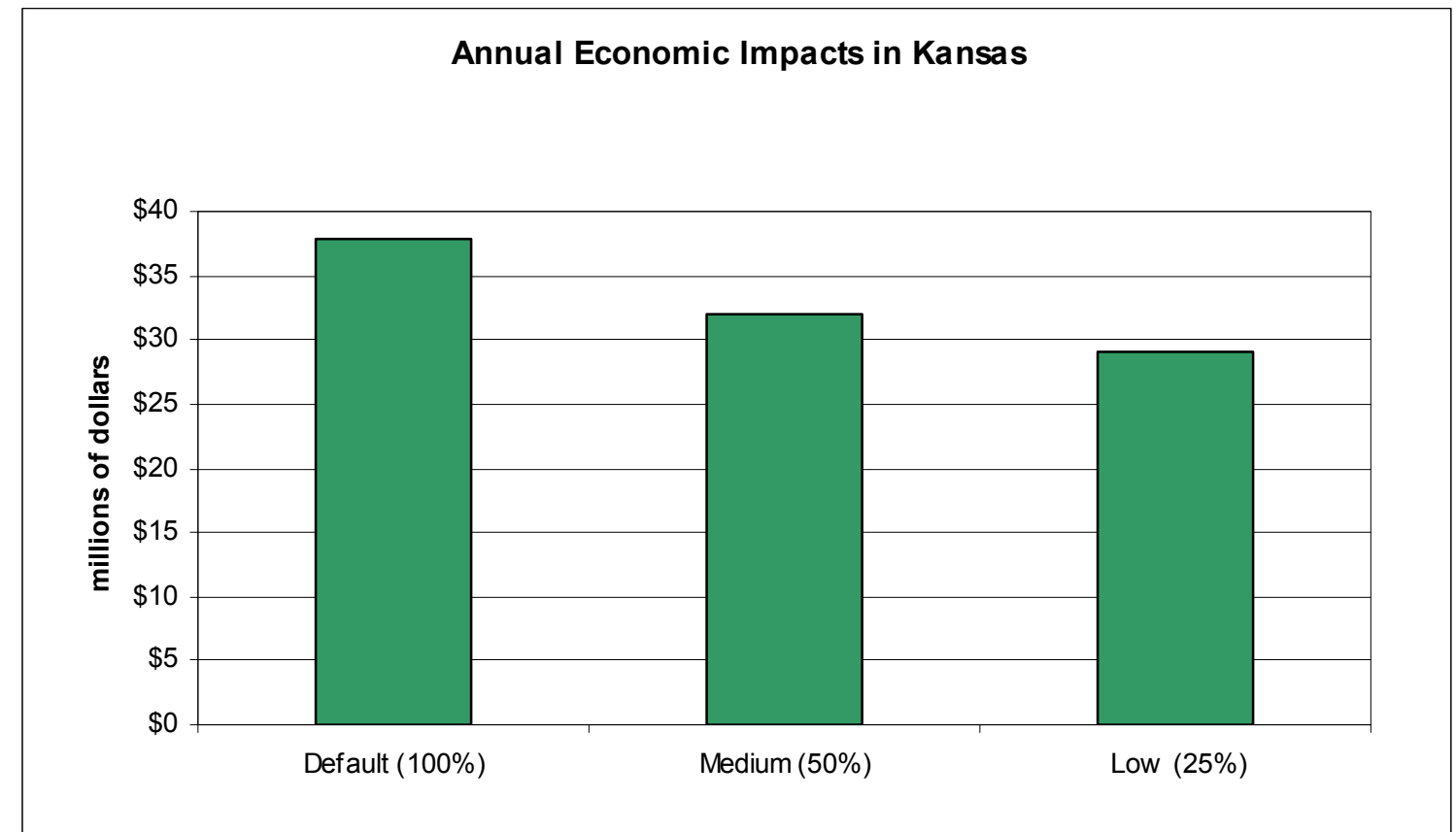

Figure 7. Implications of declining reliance on local labor for wind plant $0 \& M$ on 1,000 MW of wind power

\section{Operations Period Materials}

Wind turbine repair materials are sometimes not available from local suppliers; because of this we use a default value of $63 \%$ in-state supply for operations period materials. Nevertheless, incremental changes in local material supply can have a notable impact on annual economic development impacts. We adjusted local material supply down to $40 \%$ and up to $75 \%$. In Kansas, if local supply of O\&M materials drops from $63 \%$ to $40 \%$, we

\footnotetext{
${ }^{25}$ This practice is not well documented in the industry, but it has been noted in a few instances. In addition, conventional generation facilities often rely more heavily on out-of-state contractors for O\&M, and we feel that as the industry consolidates and matures, this trend could increasingly predominate in the wind industry.
} 
observe a $19 \%$ decrease in annual economic benefits. In contrast, a $9 \%$ increase in annual benefits results from increasing local material supplies from $63 \%$ up to $75 \%$ (Figure 8). As was the case for labor impacts, when these increases or declines are accumulated over a 20 -year operating period, the changes are magnified such that the drop from $63 \%$ to $40 \%$ local materials is a loss of approximately $\$ 144$ million in economic output while the increase from $63 \%$ to $75 \%$ is a $\$ 71$ million dollar increase in economic output over the life of the project.

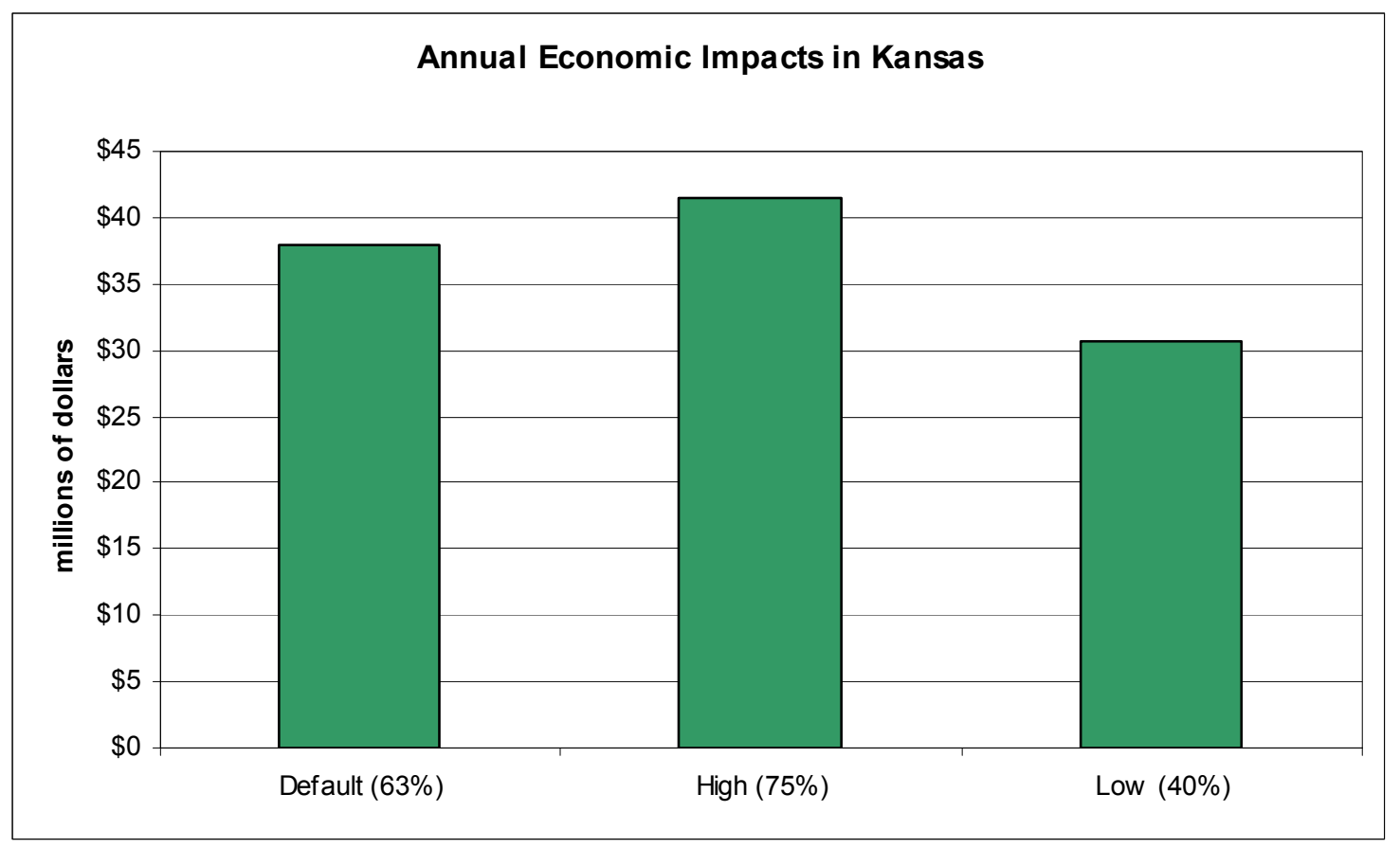

Figure 8. Implications of variable $0 \& M$ materials sourcing for 1,000 MW of wind power

\section{Summary}

If a policymaker or stakeholder is interested primarily in the economic development benefits of building wind power, the single greatest means of insuring increased development benefits is to increase the use of local labor and components throughout the construction and operations period. However, our research shows that targeting policies to specific aspects of wind power development and operations may be more efficient at increasing the economic development benefits associated with building wind power plants.

Attracting wind power manufacturing to one's state and using this manufacturing for instate wind power projects has been shown to dramatically enhance economic development. Furthermore, wind power manufacturing in a given state allows it to realize economic benefits from wind development in other states that do not have their own local supply of wind power materials and components. On a secondary level, creating policies to ensure maintenance materials are supplied by in-state business and that the local labor force is trained to perform wind turbine maintenance is also likely to have a large impact for wind power plants operating for 20 or more years. In contrast, policies geared toward 
training a construction workforce are less likely to have an impact on total economic development benefits.

\section{Local Ownership of Wind Projects}

In addition to local labor and components, in-state economic benefits can be enhanced by local ownership of wind projects. Literature in the past has generally associated the increased economic benefits with an increased preference for local labor and materials during construction and operations as well as the cash inflow that results from the energy sales. Economic development impacts in these studies have typically been focused on county-level analyses and have varied widely (Goldberg et al., 2004, Galluzo 2005, and Kildergaard 2006).

Our analysis of local ownership was performed at the state level. Therefore, our economic development impact results are likely to be greater in magnitude than countylevel local ownership analyses. However, our analyses result in a lower percent change because county-level benefits are typically much smaller and therefore more dramatically affected on a percentage basis by a given change in local benefits. As such, it is difficult to compare the ratio of benefits between corporate- and locally owned projects with the same ratios that were developed in previous analysis of county-level economic impacts.

In addition, this analysis of local ownership and economic development is intended to represent preliminary work and provide a general order of magnitude assessment of the difference in benefits associated with locally owned projects versus corporate-owned projects.

\section{Local Ownership Structures}

We modeled two types of local ownership structures; both local ownership scenarios are all-equity scenarios. For both scenarios, we demonstrated a preference for local construction labor and materials. To do so, we adjusted the share of local components and labor during the construction period to the maximum level that we believe is generally attainable, given the variability we currently observe in individual projects. Rather than calculating expected returns based on variable power purchase agreements, tax liabilities, and efficient use of the PTC, we assigned an expected plausible rate of return for the individual equity that is in accordance with typical returns from these projects. ${ }^{26}$ The rate of return for local equity investors in both of our local ownership models was set at $9 \%$.

The first ownership structure is a 100\%-local equity structure in which a variety of local residents invest small amounts of capital in the project. Based on the Minwind projects, developed in Southwestern Minnesota, ${ }^{27}$ this ownership structure involves a large number of investors and allows for relatively high efficiency or potentially even full value use of the production tax credit (PTC). ${ }^{28}$ In the first scenario, benefits were

\footnotetext{
${ }^{26}$ This value is based on an interview with an active community wind developer, who noted that a typical, approximate, estimated return on investment for locally owned projects is $8 \%$ to $10 \%$.

${ }^{27}$ For more information, see http://www.windustry.org/minwind-iii-ix-luverne-mn-community-windproject

${ }^{28}$ This can occur through aggregation of the small passive tax appetite of a large number of individual investors.
} 
calculated annually with $100 \%$ of investors accruing a 9\% return on investment; we assumed that the full value of the cash return remains in the local community. ${ }^{29}$

The second investment scenario relies on a "flip" model of wind power development. This version is most closely aligned with the "strategic investor flip" as described by Harper et al. (2007). In this specific case, we assume local equity investors maintain a 1\% stake in the project over the first 10 years of operations and receive $1 \%$ of the sum of the cash and tax benefits accrued over this time. Subsequently, after year 10, we assume local investors buy out the strategic tax investor. At this point, the local investors acquire full ownership and a $100 \%$ equity stake, thereby providing them with $100 \%$ of the cash benefits during years 11 to 20 of operations. This equity structure results in an average annual ownership value of $51 \%$, for which they receive the $9 \%$ return on investment noted above. As in the first scenario, we assume the full value of the cash return is reinvested in the local community.

\section{Results}

Under these conditions, we determined the state-level construction period economic development benefits of local ownership to be $7 \%$ greater than those incurred with corporate-developed and -owned projects. However, this increased benefit is based on the ability of local owners to acquire increased levels of local labor and materials versus corporate developers (Figures 9 and 10). The increased benefit is equivalent during the construction period under both local ownership scenarios.

The relatively marginal increased benefit that occurs during the construction period is primarily the result of the high levels of local labor and material reliance that are commonly associated with corporate-owned projects. As a result, an increased preference for local labor and materials does not provide a large magnitude change. ${ }^{30}$

During the operating years, annual economic benefits are notably higher for locally owned wind projects than for corporate ownership. The $100 \%$ local equity projects are observed to have an annual impact that is $164 \%$ greater than corporate-owned projects. The $51 \%$ local equity scenario, representative of a strategic investor flip, results in a $79 \%$ greater local economic output than an equivalent corporate-owned project (Figures 9 and 10). These results are due to the cash inflow, in the form of profits, at a $9 \%$ annual return on investment.

\footnotetext{
${ }^{29}$ This may or may not reflect the actual on the ground conditions. However, we lacked data suggesting how this money might be spent. To the extent that individual investors reinvest or spend their returns outside of the state, the economic benefits resulting from these scenarios are diminished.

${ }^{30}$ While we feel this conclusion is justified, it should be noted that there may be significant variability construction period impacts between projects. Recent evidence suggests that on an individual project basis, local labor supplies may vary from the expected value that we utilized in our JEDI modeling. As a result, in some instances the increased preference for local labor that is commonly associated with local ownership may play a greater role than our results suggest.
} 


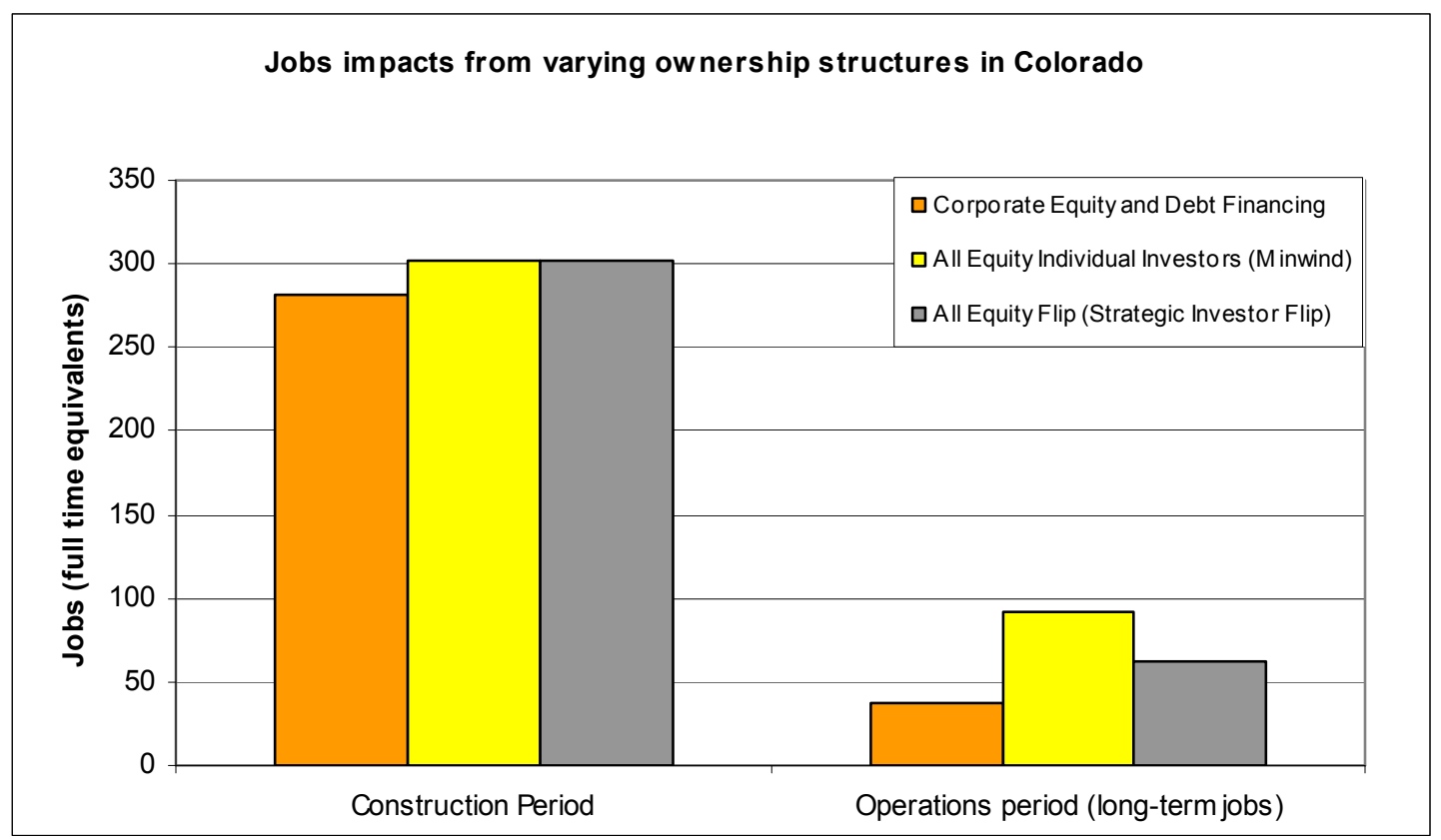

Figure 9. Jobs impacts from varying ownership structures in Colorado

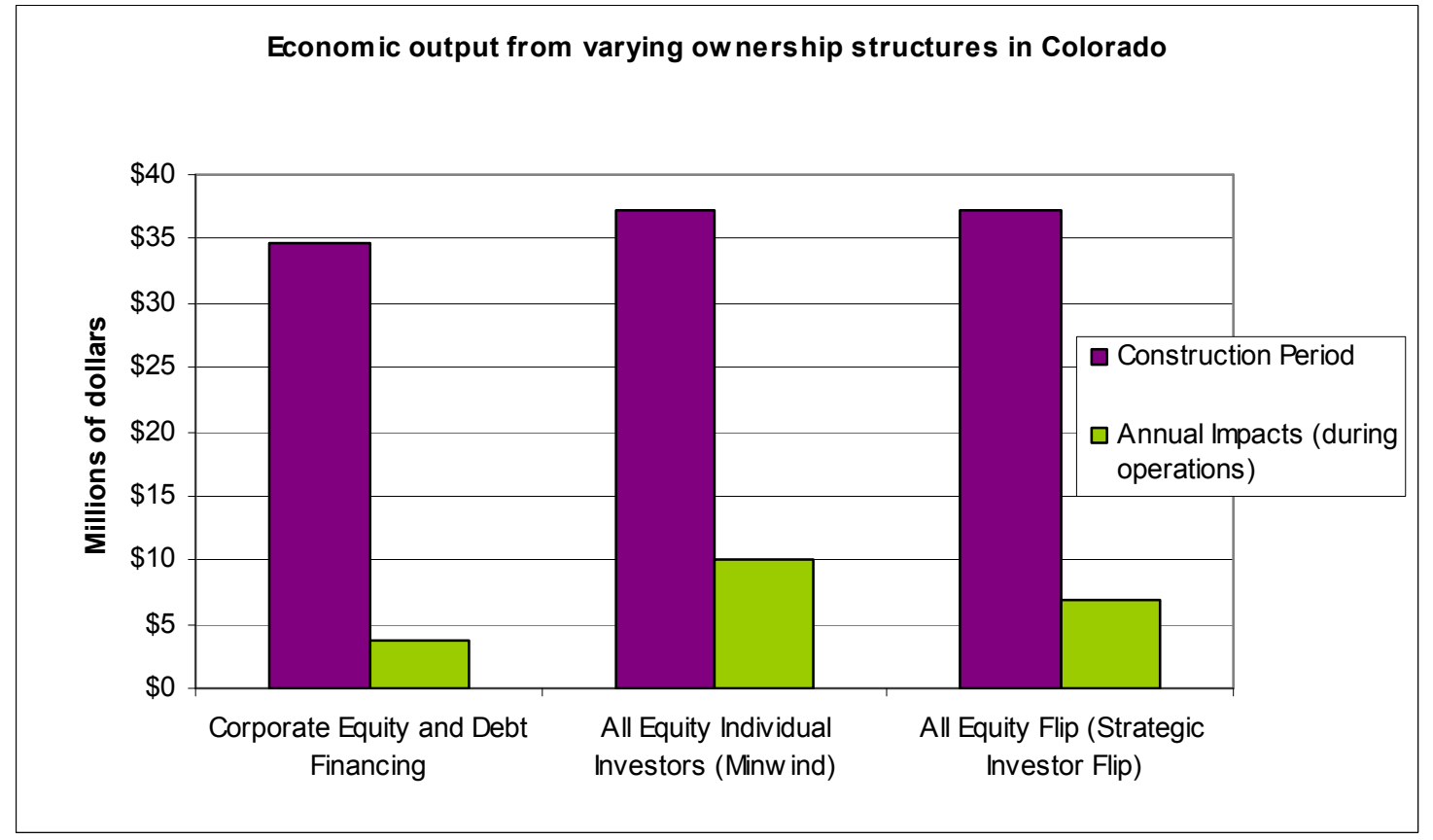

Figure 10. Economic output from varying ownership structures in Colorado

One critical caveat in modeling local ownership implications is that we assume a 9\% return is achieved for these projects. This assumes such projects are profitable and performing at this rate. Furthermore, this does not account for the opportunity cost of capital. Assuming that local investors can obtain a 5\% annual yield from alternative investments means that the net economic impact from a locally owned project depends on the potential availability of alternative investments that may be more or less profitable than the wind farm. As such, what we demonstrate is the gross magnitude of benefits that 
results from investment in a locally owned wind power project rather than the net benefit that accrues from such an investment.

A second caveat is that we assume that the total return on investment is initially reinvested, or spent, in the state where the project is located. Performing these analyses at the state level, rather than limiting them to the county, increases the likelihood that investment returns are spent locally; however, to the extent that an investor utilizes his or her return to purchase goods manufactured out of state or pursue investment opportunities located out of state, the economic benefit will be diminished.

\section{Comparing Economic Development of Wind and Coal Power}

This portion of the analysis highlights the economic development benefits of equivalent power-generating wind and coal-fired facilities. Before discussing the results of this analysis, it is important to highlight two considerations. First, capacity factor is critical. Wind power generally operates at a capacity factor that is much lower than coal power plants, $30 \%$ to $45 \%$ versus $85 \%$. As a result, a significantly greater proportion of wind power in nameplate capacity must be constructed for the power output to be equivalent to a given coal power plant. However, economic development benefits are associated with the magnitude of the investment in a new power-generating facility. Assuming a similar local supply of labor, components, and materials, a project with a larger total investment will have larger economic development impacts. Therefore, lower capacity factor wind projects may have greater economic development benefits per unit of energy generated. It may be argued that because of capacity factor disparity, it is unfair to compare economic development benefits from equivalent energy-producing facilities.

We offer two responses to this argument. First, wind power has no fuel costs, so increased capital costs are countered by lower operating costs. In addition, local fuel sources enhance the economic development benefits of coal power. Second, evaluating the levelized cost of these generation resources reveals that on a per-unit energy basis, prices are comparable (O'Connell and Pletka 2007). Therefore, as long as a project is economically viable, a lower capacity factor should not discount the economic development benefits. In other words, if the cost of energy from wind power is comparable to that of coal, then the difference in nameplate capacity installments required for a given energy equivalent analysis should not be a consideration when comparing different power generation technologies.

Likewise, low-wind-speed sites, with similar local supply parameters to high-wind-speed sites, have a greater economic development impact than high-wind-speed sites.

Nevertheless, as long as the levelized cost of energy is competitive with other generators in power markets, capacity factor and the associated nameplate capacity required for a given project should not be a factor in economic development analysis.

Much like the other research conducted for this paper, we forecast economic development benefits with the NREL-sponsored JEDI models. Likewise, for this portion of the analysis we utilized data collected from interviews conducted with state-specific electric industry contacts and local tax officials. In addition, we used federal energy 
databases, press releases of proposed new wind and coal facilities, and state mining association data to supplement and validate information acquired through interviews.

NREL's JEDI wind model is publicly available and has been widely applied for analysis of wind power projects. The JEDI coal model has been peer reviewed but has not yet been released to the public. Both models were developed by Marshall Goldberg at MRG \& Associates for NREL.

\section{Results}

The results of our analyses demonstrate that in Kansas and Michigan, the economic development benefit of wind is clearly greater than that of coal. In Kansas, our research suggests that wind power will result in a $31 \%$ greater economic development benefit than coal power (Figure 11). Likewise in Michigan, the expected economic development benefit is 93\% greater than a similar energy-producing coal power facility (Figure 12).

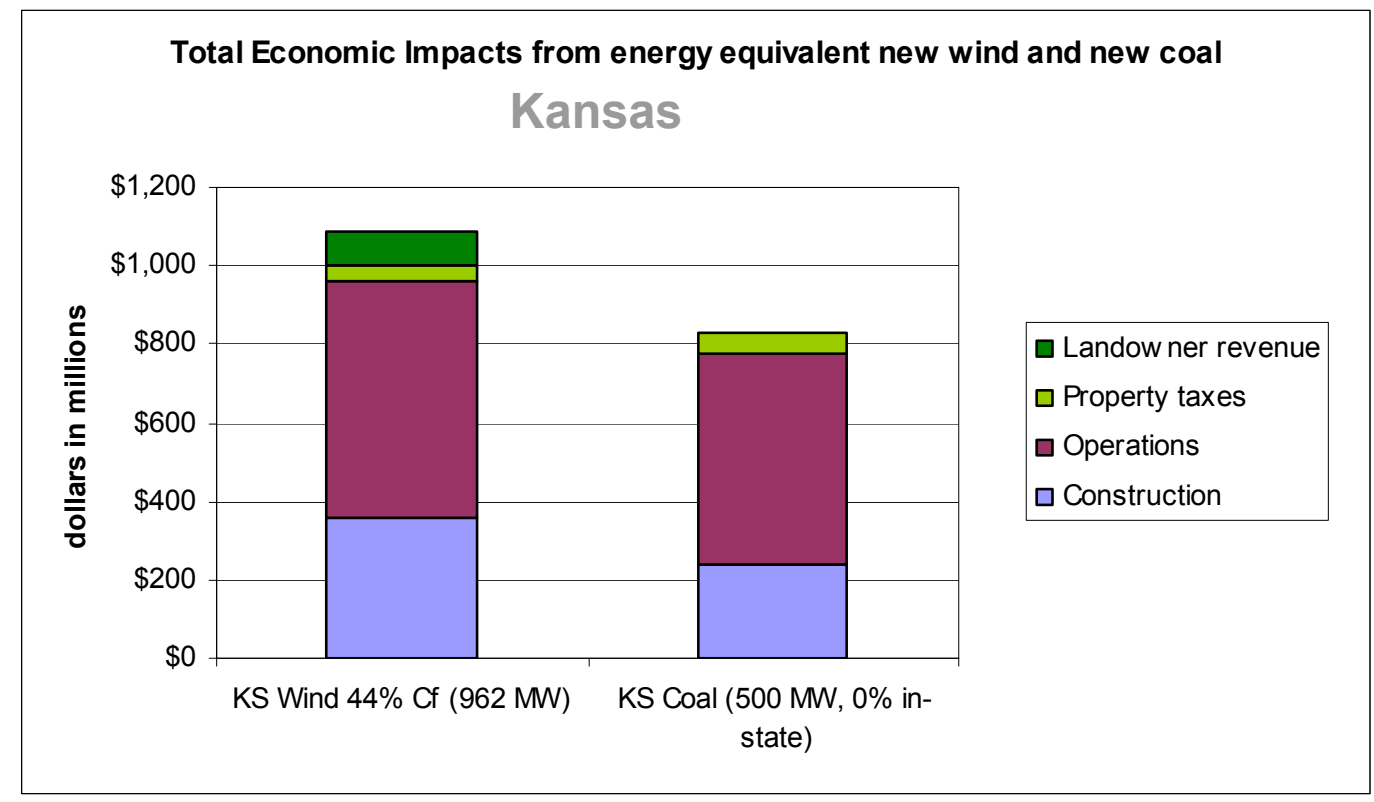

Figure 11. Comparing wind power and coal power economic development impacts in Kansas 


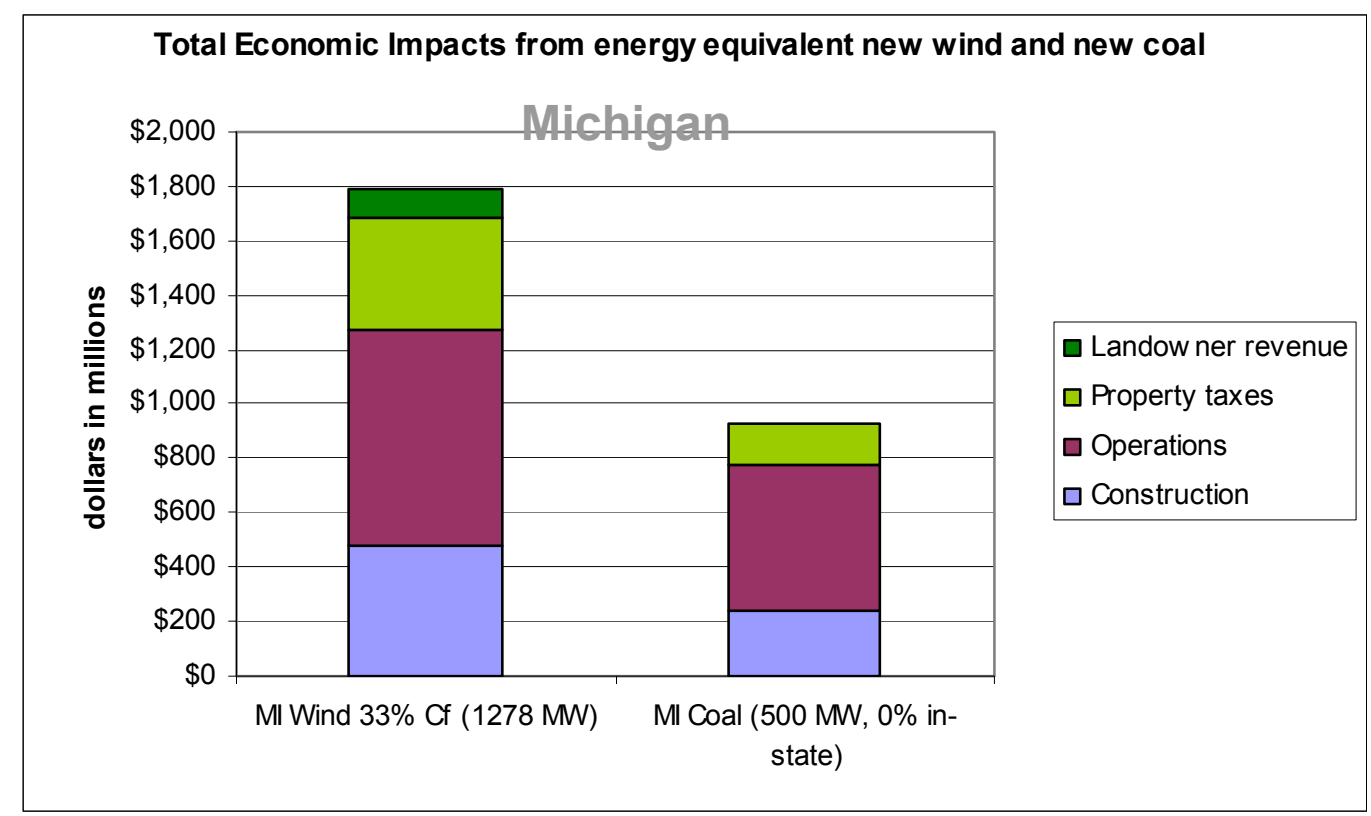

Figure 12. Comparing wind power and coal power economic development impacts in Michigan

In Colorado, our results require a higher degree of nuance because of Colorado's coal mining industry. In addition, we show the economic development benefits in Colorado for development at high- and low-wind-speed sites (Figure 14).

Recent analysis of EIA data shows that in 2006, Colorado coal supplied 55\% of the state's coal-powered electricity generation needs. However, depending on the location of a new coal power plant, it may or may not receive Colorado coal. Assuming that a new $500-\mathrm{MW}$ coal power plant receives the same proportion of Colorado coal that was determined for the Colorado electricity sector in 2006 means that a significant benefit for the state's coal mining industry will result from a new power plant. Subsequently, this has a dramatic impact on the economic development benefits of coal power. However, past research suggests that a new coal power facility on the Front Range in Colorado is likely to be supplied by Wyoming Powder River Basin coal (Tegen 2006 and Xcel Energy 2004). If this is indeed the reality, then no in-state benefit accrues from coal consumption, and the economic development benefit of coal power is reduced. In short, when local coal is consumed, coal power often has similar or in some cases a greater economic development benefit than wind power. Figure 13 highlights states that rely on in-state coal resources for electricity generation. 


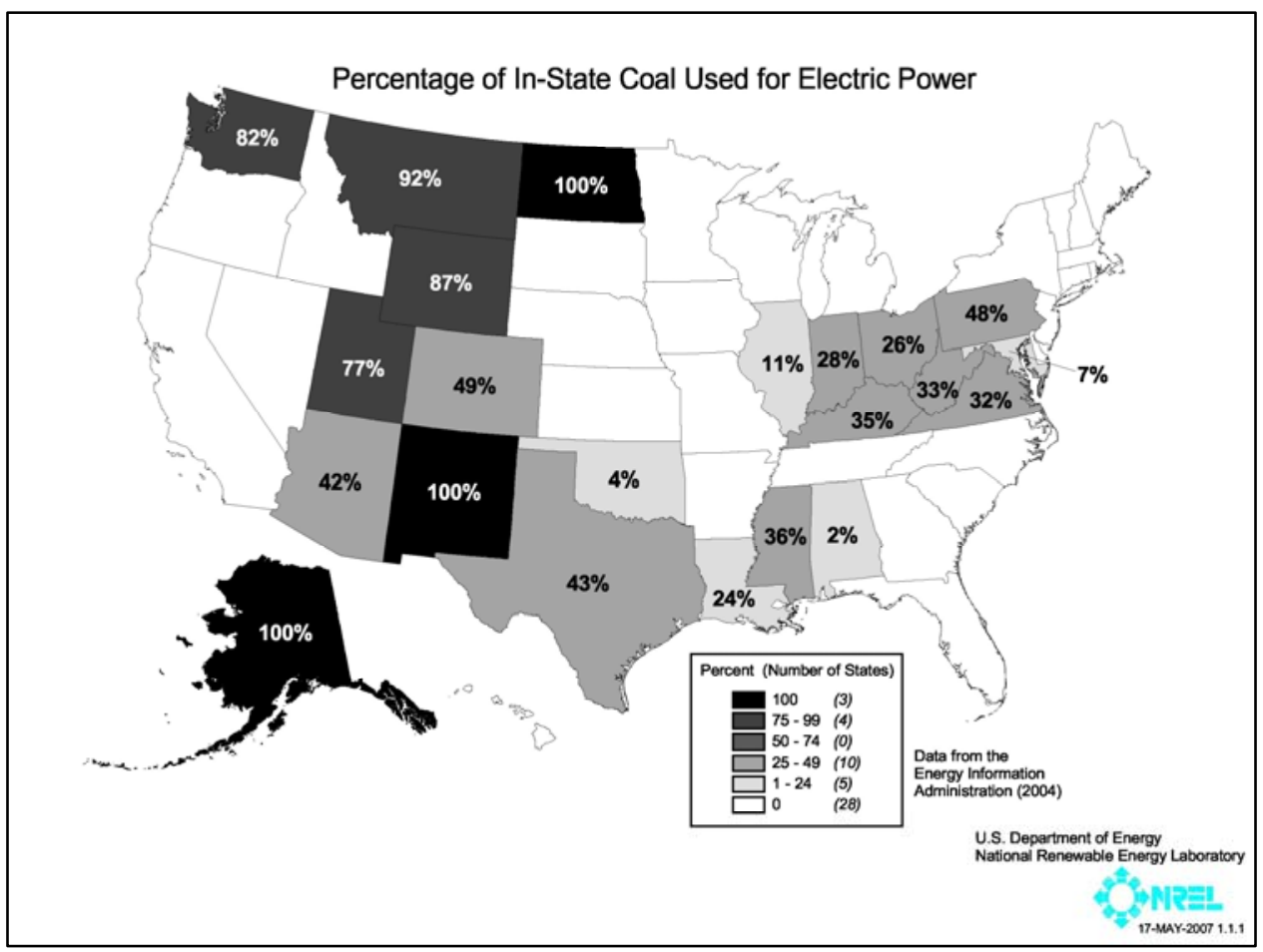

Figure 13. Percentage of coal consumed for electric power generation that is supplied from in-state coal resources ${ }^{31}$

Assuming high capacity factor wind development (43\%) and a new coal power plant that utilizes 55\% Colorado coal, coal power economic development benefits exceed wind power by approximately $50 \%$. Assuming profitable wind development at a $35 \%$ capacity factor and 55\% reliance on Colorado coal, the benefit of coal over wind is reduced to $17 \%$. In contrast, if we assume all the coal for a new coal-fired facility is supplied by Wyoming Powder River Basin coal, wind power economic development benefits are 32\% and $61 \%$ greater than coal for the high- and low-capacity-factor scenarios respectively (Figure 14).

${ }^{31}$ Calculated by NREL from EIA 2004 data 


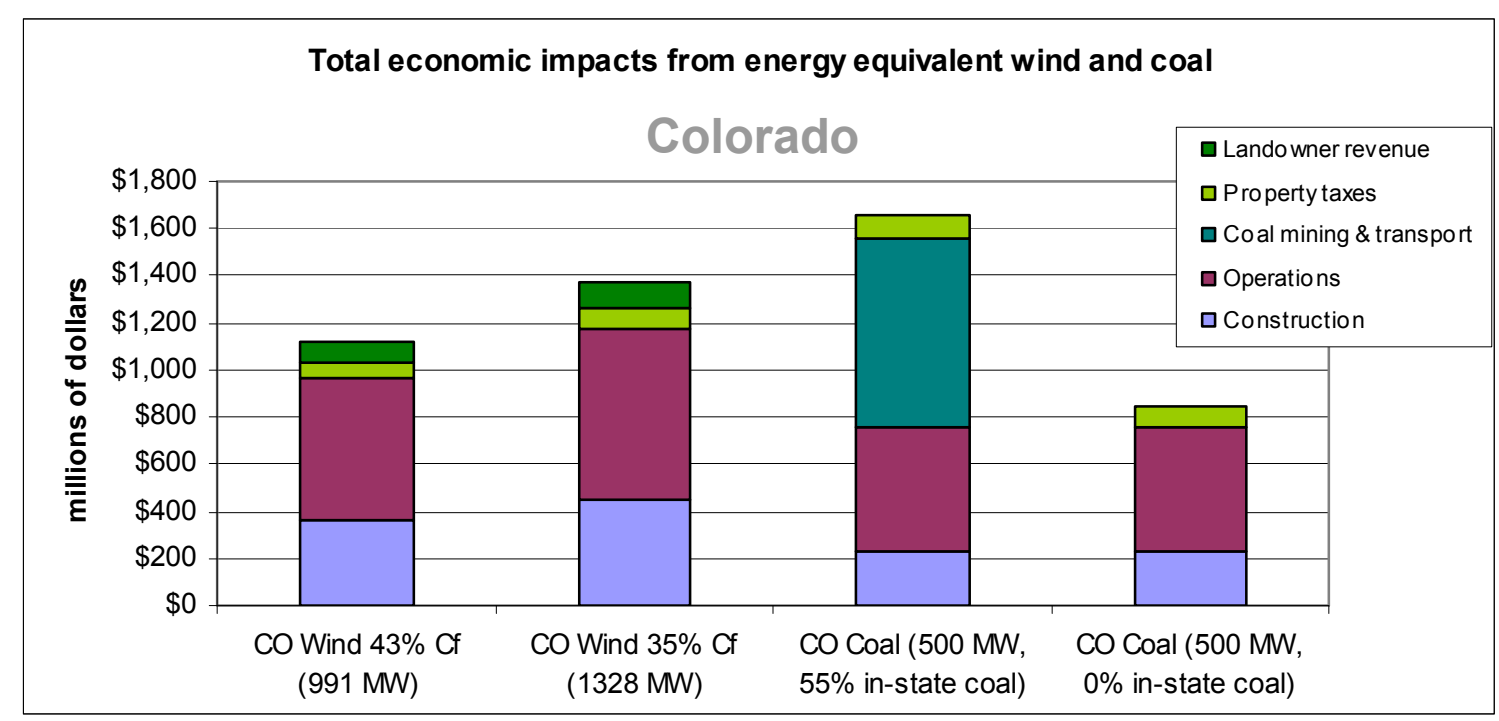

Figure 14. Comparing wind power and coal power economic development impacts

When comparing wind and coal, it is also worthwhile to note that the domestic wind power manufacturing industry is undergoing rapid growth. As noted above, wind turbines account for $65 \%$ to $85 \%$ of the entire construction costs of new wind facilities. However, at present, the majority of wind turbines installed in the United States are imported. If states are able to secure and develop new wind turbine manufacturing, as Iowa has done, the economic benefits of wind power could greatly exceed coal power, even in states where local coal mining is a dominant industry.

\section{Conclusion}

Energy policies are driven by a variety of values and interests. As new electricity generation technologies have become more prevalent, policymakers increasingly make decisions based on a more holistic understanding of the costs and benefits of different forms of electricity generation. One of the impacts to consider in this more inclusive portfolio of costs and benefits is the economic development impact of energy investments on a decision-maker's local constituency.

We have demonstrated with this analysis that a variety of factors must be considered when conducting economic development analysis and that policies intended to enhance economic development from wind power can be more efficient if targeted to specific facets of the wind industry. In addition, not only is the magnitude of the impact important but also the type of impact and the specific constituency that a policymaker hopes to benefit. This is especially critical when evaluating property tax and land lease payments.

Any policy that will facilitate the use of local labor, materials, and components for wind projects will increase local economic impacts of wind projects. Policies that attract local wind power manufacturing are likely to have the greatest impact on total economic development benefits. Following local manufacturing, it is the operations period labor and materials that are most likely to drive the total economic impact. In contrast, emphasizing construction workforce training to increase use of local construction labor 
may not be as efficient a use of limited policy resources as workforce training to increase use of local manufacturing, materials, and labor during the operating period of the wind farm's life.

As with any economic forecast, the specific results of this analysis are subject to variability based on individual project specifics and changes within the wind industry. However, policymakers seeking to increase the local benefits that will result from the rapid growth of the wind industry can influence policy so that their constituents are able to participate in the wind manufacturing and maintenance industries. Pursuing policies that support these wind development aspects are likely to provide the greatest economic development benefit for states from the growing wind industry. 


\section{Bibliography}

Galluzzo, T.W. (2005). Small Packages, Big Benefits: Economic Advantages of Local Wind Projects. The Iowa Policy Project. Mount Vernon, IA.

http://www.iowapolicyproject.org/2005docs/050405-wind.pdf Accessed June 9, 2008.

Goldberg, M.; Milligan, M.; Sinclair, K. (2004). Jobs and Economic Development Impact (JEDI) Model: A User-Friendly Tool to Calculate Economic Impacts from Wind Projects. NREL/CP-500-35953 Golden, CO. National Renewable Energy Laboratory. http://www.nrel.gov/docs/fy04osti/35953.pdf Accessed June 9, 2008.

Harper, J.P.; Karcher, M.D. Bolinger, M. (2007). Wind Project Financing Structures: A Review and Comparative Analysis. LBNL-63434. Berkeley, CA. Lawrence Berkeley National Laboratory. http://eetd.lbl.gov/ea/emp/reports/63434.pdf Accessed June 9, 2008.

Kildergaard, A.; Myers-Kuykindall, J. (2006). Community vs. Corporate Wind: Does it matter who develops the wind in Big Stone County, MN? IREE Grant No. SG P4c 2004. Initiative for Renewable Energy and the Environment at the University of Minnesota. http://cda.mrs.umn.edu/ kildegac/CV/Papers/IREE.pdf Accessed June 9, 2008.

Levesque, C. 2008. States Bolster Wind Turbine Supply Chain. North America Wind Power 5:5 June 2008.

Massachusetts Institute of Technology (MIT). (2007). The Future of Coal: An Interdiscplinary MIT Study. ISBN 978-0-615-14092-6. Massachusetts Institute of Technology. http://web.mit.edu/coal/ Accessed June 9, 2008.

Milford, J.; Nielsen, J.; Patton, V.; Ryan, N.; White, J.V.; Copeland, C.; (2005).Clearing California's Coal Shadow from the American West. Environmental Defense. http://www.westernresourceadvocates.org/media/pdf/CA\%20Coal\%20Shadow.pdf Accessed June 9, 2008.

Milford, J.; Spencer, N.; Gilbert, C.; Nielsen, J.; Patton, V. (2007). Climate Alert: Cleaner Energy for the Southwest. Environmental Defense. http://www.westernresourceadvocates.org/media/pdf/ClimateAlertReport.pdf. Accessed June 9, 2008.

NREL Economic Development Database. As part of the National Renewable Energy Laboratories Wind Powering America Program, NREL analysts maintain a growing database of economic development impacts measured from on the ground projects that are in operation today. Such data is derived from interviews with wind power project developers, local tax assessors, and other industry experts. 
O’Connell, R.; Pletka, R.; (2007). 20 Percent Wind Energy Penetration in the United States: A technical Analysis of the Energy Resource. Overland Park, KS: Black and Veatch. http://20percentwind.org/Black_Veatch_20_Percent_Report.pdf Accessed June 9, 2008.

Office of the Governor of Kansas. Sebelius prevents and reduces pollutants with veto, executive order. Nicole Corcoran Press Secretary. March 21,2008. http://www.governor.ks.gov/news/NewsRelease/2008/nr-08-0321a.htm Accessed June 9, 2008.

Personal Communication. Treasurers Office, Prowers County, Colorado. Spring 2008.

Tegen, S. (2006). Comparing Statewide Economic Impacts of New Generation from Wind, Coal, and Natural Gas in Arizona, Colorado, and Michigan. NREL/TP-50037720. Golden, CO. National Renewable Energy Laboratory. http://www.nrel.gov/wind/pubs issues.html Accessed June 9, 2008.

U.S. Department of Energy. Annual Energy Outlook 2008. Energy Information Administration. http://www.eia.doe.gov/oiaf/aeo/electricity.html. Accessed June 9, 2008.

Wind Industry Asks Gov. Granholm and Senator Patterson to Make 'Fresh Start' With Renewable Energy Legislation, Opposes Recent House Bills. AWEA Press release May 6, 2008.

http://awea.org/newsroom/releases/AWEA_requests_fresh_start_renewable_energy_legis lation_06May2008.html. Accessed June 9, 2008.

Wiser, R.; Bolinger, M.; (2008). Annual Report on U.S. Wind power Installation, Cost, and Performance Trends: 2007. DOE/GO-102008-2590. Berkeley, CA. Lawrence Berkeley National Laboratory. http://www.nrel.gov/docs/fy08osti/43025.pdf Accessed June 9, 2008.

Xcel Energy. Planning for Colorado's Growing Energy Needs: Proposed New Unit at Comanche Station near Pueblo. Golden, CO. Proposed Project Factsheet. http://www.xcelenergy.com/docs/corpcomm/ComancheProposedUnit3FactSheet.pdf Accessed June 9, 2008. 


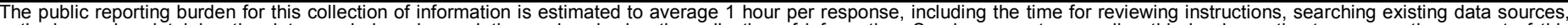

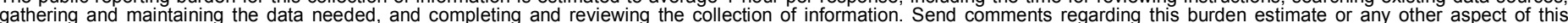

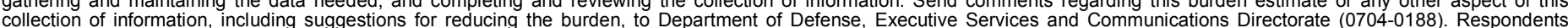

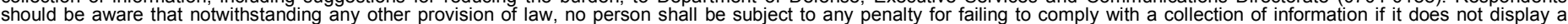

should be aware that notwithstandin.

PLEASE DO NOT RETURN YOUR FORM TO THE ABOVE ORGANIZATION.

\begin{tabular}{l|l|l|l} 
1. REPORT DATE $(D D-M M-Y Y Y Y)$ & 2. & REPORT TYPE & 3. DATES COVERED (FrOm - TO)
\end{tabular}

July 2008

Conference Paper

4. TITLE AND SUBTITLE

Variables Affecting Economic Development of Wind Energy

5a. CONTRACT NUMBER

DE-AC36-99-G010337

5b. GRANT NUMBER

5c. PROGRAM ELEMENT NUMBER

6. AUTHOR(S)

E. Lantz and S. Tegen

5d. PROJECT NUMBER

NREL/CP-500-43506

5e. TASK NUMBER

WER84006

5f. WORK UNIT NUMBER
7. PERFORMING ORGANIZATION NAME(S) AND ADDRESS(ES)

National Renewable Energy Laboratory

1617 Cole Blvd.

Golden, CO 80401-3393
8. PERFORMING ORGANIZATION REPORT NUMBER

NREL/CP-500-43506

9. SPONSORING/MONITORING AGENCY NAME(S) AND ADDRESS(ES)

10. SPONSOR/MONITOR'S ACRONYM(S) NREL

11. SPONSORING/MONITORING AGENCY REPORT NUMBER

12. DISTRIBUTION AVAILABILITY STATEMENT

National Technical Information Service

U.S. Department of Commerce

5285 Port Royal Road

Springfield, VA 22161

13. SUPPLEMENTARY NOTES

14. ABSTRACT (Maximum 200 Words)

We used the National Renewable Energy Laboratory's (NREL's) latest Jobs and Economic Development Impacts Wind (JEDI Wind) model to perform a sensitivity analysis of wind-power-related economic development drivers, and economic development benefits for wind and coal were estimated using NREL's JEDI Wind and JEDI Coal models. Our research shows that economic development impacts can be dramatically enhanced through the development of local wind power manufacturing industries.

15. SUBJECT TERMS

wind; wind energy; economic development; JEDI Model; Jobs and Economic Development Impacts Model; economic model; wind versus coal

\begin{tabular}{|c|c|c|}
\hline $\begin{array}{l}\text { a. REPORT } \\
\text { Unclassified }\end{array}$ & $\begin{array}{l}\text { b. ABSTRACT } \\
\text { Unclassified }\end{array}$ & $\begin{array}{l}\text { c. THIS PAGE } \\
\text { Unclassified }\end{array}$ \\
\hline
\end{tabular}

\begin{tabular}{|c|c|}
\hline $\begin{array}{l}\text { 17. LIMITATION } \\
\text { OF ABSTRACT }\end{array}$ & $\begin{array}{l}\text { 18. NUMBER } \\
\text { OF PAGES }\end{array}$ \\
\hline UL & \\
\hline
\end{tabular}

19a. NAME OF RESPONSIBLE PERSON

19b. TELEPHONE NUMBER (Include area code) 